\title{
ACRL New England Chapter: First Election
}

At a business session held in conjunction with the Conference on Writing and Publishing sponsored by the ACRL New England Chapter at Brandeis University on April 4, 1975, results of the first election of chapter officers were announced. Elected were:

George R. Parks, dean, University Libraries, University of Rhode Island, as president for the remainder of 1975 ;

Diane Lutz, assistant librarian, New Hampshire College, as president-elect for the remainder of 1975 and president for 1976 ;

Elizabeth P. Mitchell, editorial librarian, Harvard University Libraries, as secretary for 1975 and 1976; and

Anne M. Conway, cataloger, MCLP Project, University of Massachusetts, Amherst Library, as treasurer for 1975 and 1976.

Since its establishment by action of the ACRL Board of Directors on June 29, 1972, the New England Chapter has been directed by a
Steering Committee consisting of Thomas $\mathbf{H}$. Cahalan of Northeastern University, Mary D. McFeely of Smith College, Richard A. Olsen of Rhode Island College, and Roger J. Poulin of Vermont Technical College.

The chapter has sponsored programs on standards for academic librarians, collection development, and bibliographic instruction and cosponsored a meeting with the Connecticut $\mathrm{Li}$ brary Association College and University Section on the ARL Management Review and Analysis Program (MRAP). A Chapter Bylaws Committee, established to assist in organizational development and planning, includes Anne C. Edmonds of Mount Holyoke College (chairperson), Doris R. Brown of the University of Connecticut, Joseph $\mathrm{H}$. Doherty of Providence College, Diane Lutz of New Hampshire College, Joseph T. Popecki of St. Michael's College, Winooski, Vermont, and one person to be appointed from Maine.

\section{ACRL and ALA Representatives}

\section{at Academic Ceremonies and Meetings}

The Association of College and Research Librarieś and the American Library Association regularly receive invitations to send representatives to a variety of academic ceremonies and meetings. During the past year, members of ACRL have represented the association at the 100-year anniversary celebrations of two universities, at the inaugurations of college and university presidents, at the dedication of a new university library building, and at the annual meetings of other associations.

In June 1974, Dr. Harry Robinson, Jr., director of learning resources services at Alabama State University, Montgomery, served as ALA's and ACRL's representative on the 100-year celebration day of that university. The Centennial Convocation of the University of Nevada, Reno, held on October 12, was attended by Gordon P. Martin, university librarian at California State University, Sacramento.

David E. Estes, assistant university librarian for special collections at Emory University, represented the association at the June 1974 in- auguration of Marvin Banks Perry, Jr., as president of Agnes Scott College. On September 26, Dr. James K. Zink, director of university libraries at the University of Oklahoma, attended the inauguration of J. Terry Johnson as third president of Oklahoma Christian College. The inauguration of Thomas Bonner as president of Union College, Schenectady, New York, and chancellor of Union University, Albany, held on October 5, was attended by E. J. Josey, chief, Bureau of Academic and Research Libraries in the New York State Education Department. Dr. Billy R. Wilkinson, staff relations officer for the New York Public Library, served as the association's representative at the inauguration of Harold Proshanksy as second president of the Graduate School and University Center of the City University of New York, on October 10, 1974. Gordon P. Martin, university librarian at California State University, Sacramento, attended the inauguration of Max Milam as president of the University of $\mathrm{Ne}$ vada, Reno, held on October 12 in conjunction 